\title{
Resource Use Efficiency of Rice Farmers Participating in Value Chain Development Programme (VCDP) in Niger State of Nigeria
}

\author{
Sadiq, M.S ${ }^{1^{*}}$, Singh, I.P. ${ }^{2}$ and Ahmad, M.M³. \\ ${ }^{1}$ Department of Agricultural Economics and Extension, FUD, Dutse, Nigeria \\ ${ }^{2}$ Department of Agricultural Economics, SKRAU, Bikaner, India \\ ${ }^{3}$ Department of Agricultural Economics, BUK, Kano, Nigeria \\ *Corresponding author: sadiqsanusi30@gmail.com (ORCID ID: 0000-0003-4336-5723)
}

Received: $21-12-2019$

Revised: 24-04-2020

Accepted: 26-05-2020

\begin{abstract}
The research empirically determined the efficiency of the productive resources used in rice production among IFAD beneficiaries in Niger State of Nigeria using field survey data of 2018 production season elicited from 111 farmers through structured questionnaire complemented with interview schedule and the representative sample size was arrived at through multi-stage sampling design. The multiple regression model which adopted ordinary least square (OLS) estimation technique was used to analyze the data collected. The empirical findings showed that the farmers were operating within the economic region of production but were not at the economic optimum point owing to inefficiency in the utilization of the available recommended technologies at their disposal coupled with market imperfections. Thus, sequel to this, the study recommends the need for capacity building for the farmers on the recommended technologies viz. efficient extension services delivery (e.g. farmers field school) and adoption of neoclassical extension approach (farmer to farmer extension approach). In addition, provisions of consumption credit apart from the advanced production credit for the productivity of the latter and agro-inputs subsidies due to the farmers' poor economic status and the prevailing market imperfections are suggested in the studied area.

\section{Highlights}

(0 Farmers were not efficient in the utilization of the farm resources at their disposal given the available technology.

(0 There is need for capacity building so as to enhance productivity of rice in the studied area.
\end{abstract}

Keywords: Resource, productivity, IFAD/VCDP, rice farmers, Nigeria

It has been reported by Babatunde (2006) that especially in the developing countries such as Nigeria, the concern over the alarming rate of poverty level and the need for its alleviation as a means of enhancing the living standard of the people has led to the conceptualization and implementation of various poverty alleviation programmes worldwide among which International Fund for Agricultural Development (IFAD) was initiated. Rapid agricultural growth still remains the surest and possible way to poverty reduction in Nigeria. The IFAD support to the Nigerian Government's poverty reduction programme in rural areas is essentially people-centered with its target groups being the share labourers, landless, marginal and small-scale farmers who major in the sub-Saharan farming population (IFAD, 2013). Thus,

\footnotetext{
How to cite this article: Sadiq, M.S., Singh, I.P. and Ahmad, M.M. (2020). Resource use efficiency of rice farmers participating in value chain development programme (VCDP) in Niger state of Nigeria. Economic Affairs, 65(2): 129-136.
}

Source of Support: None; Conflict of Interest: None 
the IFAD supports programmes and projects that work with the communities and the smallholder farmers are the key players.

The prime motives of IFAD/VCDP programme are to enhance the food security of the food supplying population i.e. the rural population especially the resource-poor farmers; the food demanding population especially the urban population; and enhance the living standard of the targeted population especially the landless, marginal and small-scale farmers through income doubling by encouraging them to take advantage of value addition i.e. additional non-farm activities. The programme is anchored on technical support, linking farmers with input and output markets to achieve their set goals. Given the economic status of the targeted population which are mostly share labourers, landless, marginal and small-scale farmers which are resource poor, the achievement of the goals of the programme is in doubt as these categories of farmers are less likely to make a paradigm shift in their scale of production as their experiences on previous programmes makes it difficult for them to delineate totally from the conventional available technology at their disposal. From empirical observation, the yield of the participating farmers in the study area has been below the recommended output level of 7 to 8 tons. Therefore, since the farmers did not have the passion to delineate totally from the existing conventional technology available at their disposal, therefore, an alternative which will build on the already existing available technology need to be advanced in order to make the programme a success in reality, thus exiting the farmers from the economic status of resource poor. In addition, the pitfall is that most of the empirical studies on food security programmes for sub-Saharan Africa mostly abstract the programme success from the macro level to the micro level instead of the reverse situation i.e. mostly concentrate on the effect and impact of the programme on farmers income (for example Galadima 2014; Abdullahi et al. 2015; Gambo et al. 2016) when it is well known that productivity has a direct link with income. Thus, productivity still remains a thrust that requires tacit exploitation given the penchant conservative attitudes of the bulk of the farming population (small-scale farmers) in retaining the existing conventional production technology at their disposal. Based on literature reviews, to the best of our knowledge, there is little or no information on how to build on the technical capacity of the rice farmers to enable them bridge and even surpass the recommended yield level benchmarked by IFAD programme in Niger State of Nigeria. Therefore, this research aimed at determining the resource productivity of rice farmers participating in IFAD/ VCD programme in Niger State of Nigeria.

The outcome of this research will be of immense benefit as it will aid in guiding policymakers on how to make an adjustment at the farm production level which is very vital to the viability of the rural economy which inturn is indispensable to economic growth and development of Niger State in particular and the country at large. In addition, it will add to the advancement of knowledge and a basis to explore further on by the researchers especially on IFAD programme in the study area. However, the research suggests that future studies should look into the symmetric and asymmetric effects of risks and idiosyncratic factors causing yield gap among the participating farmers as the present research limited its scope to production inputs.

\section{RESEARCH METHODOLOGY}

The location of Niger state is on latitudes $8^{\circ} 20^{\prime} \mathrm{N}$ and $11^{\circ} 30^{\prime} \mathrm{N}$ of the equator and longitudes $3^{\circ} 30^{\prime} \mathrm{E}$ and $7^{\circ} 20^{\prime} \mathrm{E}$ of the GMT. The agro-ecological zone of the state is northern guinea savannah with a fringe of southern guinea savannah in Mokwa LGA. The major occupation of the inhabitants is farming and it's complemented with civil service jobs, artisanal, craftwork, Ayurveda medicines and petty trade. By using a structured questionnaire complemented with interview schedule, field survey data of 2018 cropping season were elicited from a total of 111 rice farmers sampled through a multi-stage sampling design. In the state, only five (5) Local Government Areas were chosen as the pilot phase for the programme with Agricultural Zone A (Bida) and $C$ (Kontagora) having two LGAs each namely Bida and Katcha; and, Wushishi and Kontagora respectively, while Zone $\mathrm{B}$ has one participating LGA viz. Shiroro. In the first stage, for Agricultural Zone A, one LGA viz. Katcha LGA was randomly selected; for Zone B the only participating LGA viz. Shiroro LGA was automatically selected; while for 
Zone C, Wushishi LGA was purposively selected based on its comparative advantage as rice is produce throughout the year owing to the presence of Tungan Kawo irrigation dam. In the second stage, two villages were randomly selected from each of the chosen participating LGAs. Thereafter, two active co-operative associations from each of the selected villages were randomly selected. It is worth to note that Microsoft excel inbuilt random sampling mechanism was used for the random selections of the villages and the co-operative associations. In the last stage, using the sampling frame obtained from the IFAD/VCD office (Table 1), Cochran's formula was used to determine the representative sample size. Thus, a total of 111 active rice farmers form the sample size for the study. The multiple regression model using OLS estimation technique was used to analyze the data collected. The Cochran's formula used is shown below:

$$
\begin{aligned}
& n_{\alpha}=\frac{n_{r}}{1+\frac{\left(n_{r}-1\right)}{N}} \\
& n_{r}=\frac{(1.96)^{2} p q}{e^{2}}
\end{aligned}
$$

Where:

$n_{\alpha}=$ adjusted sample size for finite population

$n_{r}=$ sample size for infinite population

$N=$ population size

$p=$ proportion of population having a particular characteristic

$$
\begin{aligned}
& q=1-p \\
& e^{2}=\text { error gap }(0.07)
\end{aligned}
$$

Thus, $p=0.40$ and $q=1-0.40=0.60$

\section{Model Specification}

The multiple regression model is presented below:

\section{Implicit form}

$$
Y=f\left(X_{1}, X_{2}, X_{3}, X_{4} \ldots \ldots, X_{n}\right)
$$

\section{Explicit form}

$$
Y_{i}=\beta_{0}+\beta_{1} X_{1}+\beta_{2} X_{2}+\beta_{3} X_{3}+\beta_{4} X_{4} \ldots \ldots+\beta_{n} X_{n}+\varepsilon_{i}
$$

\begin{tabular}{|c|c|c|c|c|}
\hline LGAs & Villages & Co-operative Associations & SF & SS \\
\hline \multirow{4}{*}{ Katcha } & Baddegi & Managi Badeggi Farmers CMPS & 24 & 10 \\
\hline & & Aminci Ebanti Twaki CMPS Ltd. & 25 & 10 \\
\hline & Edostu & Edotsu Co-Operative Credit \& Marketing CMPS & 25 & 10 \\
\hline & & Edotsu Jinjin Wugakun Yema CMPS & 25 & 10 \\
\hline \multirow[t]{4}{*}{ Shiroro } & Baha & Baha Abmajezhin Cooperative Multi-Purpose Society Ltd. & 15 & 7 \\
\hline & & Abwanubo Najeyi Development Association & 18 & 8 \\
\hline & Paigado & Paigado Achajebwa Development Farmers Soc. & 25 & 10 \\
\hline & & Paigado Farmers Cooperative Society Ltd. & 25 & 10 \\
\hline \multirow{4}{*}{ Wushishi } & Bankogi & Bankogi Alheri Farmers Coop. Multipurpose Soc Ltd. & 22 & 9 \\
\hline & & Bankogi Gwari Nasara CMPS & 16 & 7 \\
\hline & Kanko & Kanko Arewa Farmers & 25 & 10 \\
\hline & & Kanko Unguwar Ndakogi Cooperative Multipurpose Society Ltd. & 25 & 10 \\
\hline Total & & & 270 & 111 \\
\hline
\end{tabular}

Where;

$$
\begin{aligned}
& Y=\text { Output of rice }(\mathrm{kg}) \\
& X_{1}=\text { Farm size }(\mathrm{ha}) \\
& X_{2}=\text { Seeds }(\mathrm{kg}) \\
& X_{3}=\text { NPK fertilizer }(\mathrm{kg}) \\
& X_{4}=\text { Urea fertilizer }(\mathrm{kg}) \\
& X_{5}=\text { Herbicides }(\mathrm{ltr}) \\
& X_{6}=\text { family labour } \\
& X_{1}=\text { Paid labour (manday) } \\
& X_{8}=\text { depreciation on capital items (A) } \\
& \beta_{0}=\text { Intercept } \\
& \beta_{1-8}=\text { Regression coefficients } \\
& \varepsilon_{t}=\text { Stochastic }
\end{aligned}
$$

Table 1: Sampling frame of participating and non-participating farmers

Source: IFAD-VCDP farmers' database, 2018.

Note: SF and SS mean sampling frame and sample size respectively. 
The functional forms fitted into the specified equation are as follow:

(a) Linear function

$Y=\beta_{0}+\beta_{1} X_{1}+\beta_{2} X_{2}+\beta_{3} X_{3} \ldots \ldots \ldots+\beta_{n} X_{n}+\varepsilon_{t}$

$M P P=\beta$

Elasticity $=\beta * \bar{X} / \bar{Y}$

(b) Semi-log function

$\begin{aligned} Y= & \beta_{0}+\beta_{1} \log X_{1}+\beta_{2} \log X_{2}+\beta_{3} \log X_{3} \ldots \ldots \ldots \ldots \ldots \\ & +\beta_{n} \log X_{n}+\varepsilon_{t}\end{aligned}$

$M P P=\beta / \bar{X}$

Elasticity $=\beta / \bar{Y}$

(c) The Cobb Douglas (double log) function

$\log Y=\beta_{0}+\beta_{1} \log X_{1}+\beta_{2} \log X_{2}+\beta_{3} \log X_{3} \ldots \ldots$ $\ldots \ldots \ldots+\beta_{n} \log X_{n}+\varepsilon_{t}$

$M P P=\beta * \bar{X} / \bar{Y}$

Elasticity $=\beta$

(d) Exponential function

$\log Y=\beta_{0}+\beta_{1} X_{1}+\beta_{2} X_{2}+\beta_{3} X_{3} \ldots \ldots \ldots \ldots \ldots$
$\quad+\beta_{n} X_{n}+\varepsilon_{t}$

$M P P=\beta * \bar{Y}$

Elasticity $=\beta * \bar{X}$

\section{Determining technical efficiency of resource use}

The elasticity of production was used to estimate the rate of return to scale which is a measure of a firm's success in producing maximum output from a set of variable inputs.

$E P=(M P P) / A P P$

Where:

$E P=$ elasticity of production

$M P P=$ marginal physical product

$A P P=$ average physical product

If,

$E P=1:$ constant return to scale

$E P<1$ : decreasing return to scale

$E P>1$ : increasing return to scale
Marginal rate of technical substitution (MRTS)

Following Dawson and Lingard (1982); Hussain (2013); and Sadiq et al. (2018), the MRTS approach adopted is given below:

$\operatorname{MRTS}_{L / C}=\beta_{L} / \beta_{C} X C L^{-1}$

Where $M R T S_{L / C}$ represents marginal rate of substitution of input $L$ for $C$, where $\beta_{L}$ is the output elasticity of $L$ and $\beta_{C}$ is the output elasticity of $C$.

\section{Determining the allocative efficiency of resource-use}

The following ratio was used to estimate the relative efficiency of resource use $(r)$ :

$A E I=M V P / M F C$

Where:

$M F C$ or $P_{x}=$ unit cost of a particular resource $M V P=$ value added to rice output due to the use of an additional unit of input, calculated by multiplying the MPP by the unit price of output i.e. $M P P x_{i}{ }^{*} P_{y}$.

\section{Rule of Thumb}

If $r=1$, resource is efficiently utilized

If $r>1$, resource is underutilized

If $r<1$, resource is over-utilized

Economic optimum takes place where $M V P=M F C$. If $A E I$ is not equal to 1 , it suggests that resources are not efficiently utilized. Adjustments could therefore be made in the quantity of inputs used and costs in the production process to restore $r=1$ and the model is given as follows:

Divergence percentage $(D \%)=$

$$
\left(1-1 / r_{i}\right) \times 100 \text { or }\left[\frac{\left(r_{i}-1\right)}{r_{i}}\right] \times 100
$$

\section{RESULTS AND DISCUSSION}

Production efficiency of the rice farmers in the study area

The OLS estimation results of the four functional forms fitted into the specified production equation 
showed the linear regression to be the best fit as it satisfied all the needed conditions viz. economic (i.e. size and signs of the parameter estimates), statistical (i.e. the standard error and the coefficient of multiple determination) and econometric criteria (the OLS assumptions), thus chosen as the lead equation (Table 2). The diagnostic test results showed the residuals not to be normally distributed as evident by the significance of the $\mathrm{Chi}^{2}$ test at $10 \%$ degree of freedom. However, literature has shown that violation of normality assumption should not be considered a serious case as data in their natural form are not normally distributed. Furthermore, it was observed that there are no problems of heteroscedasticity and multicollinearity as indicated by the non-significance of the BreuschPegan LM test at $10 \%$ degree of freedom and the values of the predictor variables which were lower than the variance inflation factor (VIF) value of 10.0, respectively. However, the non-fit functional forms passed the residual test of normality (two functional forms) and multicollinearity but failed the test of homoscedasticity which is very important as its violation will make the least squares not reliable for prediction, thus their non-reliability for future prediction.

The observed coefficient of multiple determination $\left(R^{2}\right)$ value is 0.728 , implying that $72.8 \%$ of the variation in the rice output of the farmers was explained by the controlled variables included in the model. In addition, the significance of the F-statistics at $1 \%$ degree of freedom implies that the explanatory variables have a strong influence on the explained variable and also from the population point of view the inputs have a strong influence on the rice output. A cursory review of the results showed only size of the operational holding, NPK fertilizer and human labour to have a significant influence on the rice output as their respective estimated parameters were different from zero at

Table 2: Production determinants of rice output among IFAD beneficiaries

\begin{tabular}{|c|c|c|c|c|c|}
\hline \multirow[t]{2}{*}{ Inputs } & \multicolumn{4}{|c|}{ Ordinary least square (OLS) } & \multirow{2}{*}{$\begin{array}{l}\text { Col. Test } \\
\text { VIF (+) } \\
\end{array}$} \\
\hline & Linear (+) & Exponential & Semi-log & Double log & \\
\hline Constant & $\begin{array}{l}106.127(380.503) \\
{[0.2789]^{\mathrm{NS}}}\end{array}$ & $\begin{array}{l}7.584(0.0721) \\
{[105.2]^{* * *}}\end{array}$ & $\begin{array}{l}-9553.19(3611.59) \\
{[2.645]^{* *}}\end{array}$ & $\begin{array}{l}6.188(0.617) \\
{[10.04]^{* * *}}\end{array}$ & - \\
\hline Farm size & $\begin{array}{l}1475.41(438.83) \\
{[3.362]^{* * *}}\end{array}$ & $\begin{array}{l}0.292(0.0831) \\
{[3.516]^{* * *}}\end{array}$ & $\begin{array}{l}2109.97(677.51) \\
{[3.11]^{* * *}}\end{array}$ & $\begin{array}{l}0.435(0.116) \\
{[3.760]^{* * *}}\end{array}$ & 3.988 \\
\hline Seeds & $\begin{array}{l}3.98472(2.28357) \\
{[1.2134]^{\mathrm{NS}}}\end{array}$ & $\begin{array}{l}0.00048(0.001) \\
{[0.481]^{\mathrm{NS}}}\end{array}$ & $\begin{array}{l}331.64(321.99) \\
{[1.030]^{\mathrm{NS}}}\end{array}$ & $\begin{array}{l}0.054(0.055) \\
{[0.978]^{\mathrm{NS}}}\end{array}$ & 2.817 \\
\hline NPK & $\begin{array}{l}\text { 6.0322(2.0268) } \\
{[2.976]^{* * *}}\end{array}$ & $\begin{array}{l}0.0011(0.00038) \\
{[2.927]^{* * *}}\end{array}$ & $\begin{array}{l}1117.24(479.31) \\
{[2.33]^{* *}}\end{array}$ & $\begin{array}{l}0.214(0.082) \\
{[2.618]^{* *}}\end{array}$ & 3.039 \\
\hline Urea & $\begin{array}{l}2.05026(1.9673) \\
{[1.045]^{\mathrm{NS}}}\end{array}$ & $\begin{array}{l}0.00042(0.00075) \\
{[0.555]^{\mathrm{NS}}}\end{array}$ & $\begin{array}{l}839.34(516.13) \\
{[1.62]^{\mathrm{NS}}}\end{array}$ & $\begin{array}{l}0.120(0.088) \\
{[1.362]^{\mathrm{NS}}}\end{array}$ & 3.413 \\
\hline Herbicides & $\begin{array}{l}28.129(81.0175) \\
{[0.347]^{\mathrm{NS}}}\end{array}$ & $\begin{array}{l}0.00818(0.0153) \\
{[0.533]^{\mathrm{NS}}}\end{array}$ & $\begin{array}{l}582.72(473.85) \\
{[1.23]^{\mathrm{NS}}}\end{array}$ & $\begin{array}{l}0.083(0.081) \\
{[1.020]^{\mathrm{NS}}}\end{array}$ & 2.526 \\
\hline Family labour & $\begin{array}{l}7.4674(2.8184) \\
{[2.649]^{* * *}}\end{array}$ & $\begin{array}{l}0.00057(0.00053) \\
{[1.074]^{\mathrm{NS}}}\end{array}$ & $\begin{array}{l}144.91(163.02) \\
{[0.89]^{\mathrm{NS}}}\end{array}$ & $\begin{array}{l}0.018(0.028) \\
{[0.649]^{\mathrm{NS}}}\end{array}$ & 2.483 \\
\hline Paid labour & $\begin{array}{l}6.6226(3.588) \\
{[1.846]^{*}}\end{array}$ & $\begin{array}{l}0.00069(0.00068) \\
{[1.016]^{\mathrm{NS}}}\end{array}$ & $\begin{array}{l}105.21(156.26) \\
{[0.67]^{\mathrm{NS}}}\end{array}$ & $\begin{array}{l}0.002(0.027) \\
{[0.074]^{\mathrm{NS}}}\end{array}$ & 1.266 \\
\hline $\begin{array}{l}\text { Depreciation on } \\
\text { capital items }\end{array}$ & $\begin{array}{l}-0.01606(0.0149) \\
{[1.142]^{\mathrm{NS}}}\end{array}$ & $\begin{array}{l}-2.842 \mathrm{E}-6(1.31 \mathrm{E}-5) \\
{[0.216]^{\mathrm{NS}}}\end{array}$ & $\begin{array}{l}96.48(288.22) \\
{[0.33]^{\mathrm{NS}}}\end{array}$ & $\begin{array}{l}-0.0011(0.049) \\
{[0.022]^{\mathrm{NS}}}\end{array}$ & 2.288 \\
\hline$\Sigma \beta$ & 0.98 & & & & \\
\hline $\mathrm{R}^{2}$ & 0.728 & 0.680 & 0.660 & 0.675 & \\
\hline Adjusted $\mathrm{R}^{2}$ & 0.706 & 0.655 & 0.633 & 0.649 & \\
\hline F-stat & $33.74^{* * *}$ & $26.80^{* * *}$ & $24.47^{* * *}$ & $26.20^{* * *}$ & \\
\hline $\begin{array}{l}\text { Heteroskedasticity } \\
\text { (B-G) }\end{array}$ & $2.645\{0.234\}^{\mathrm{NS}}$ & $80.61\{0.0006\}^{* * *}$ & $77.53\{1.5 \mathrm{E}-13\}^{* * *}$ & $52.20\{1.5 \mathrm{E}-8\}^{* * *}$ & \\
\hline Normality test & $13.16\{0.0013\}^{* * *}$ & $3.865\{0.144\}^{\mathrm{NS}}$ & $17.40\{0.00016\}^{* * * *}$ & $3.07\{0.214\}^{\mathrm{NS}}$ & \\
\hline
\end{tabular}

Source: Field survey, 2018.

Note: ${ }^{* * * * * N}$ significance at $1 \%, 5 \%, 10 \%$ and Non-significant respectively.

Values in ( ); [ ]; and \{ \} are standard error, $t$-statistic and probability value, while Col. = Collinearity 
$10 \%$ degree of freedom as against others whose parameter estimates were not different from zero at $10 \%$ degree of freedom. The positive significance of farm size revealed the effects of economies of scale and land productivity in increasing rice output among the IFAD farmers. Thus, the marginal and elasticity implications of a unit increase in the rice operational holding by 1 hectare will lead to an increase in rice output by $1475.41 \mathrm{~kg}$ and $0.41 \%$ respectively. The positive significance of the NPK fertilizer indicates the availability of the agro-input owing to the subsidy, thus the adequate application of the dosage which increase the rice output in the studied area. Therefore, the marginal and elasticity implications of a unit increase in NPK fertilizer by $1 \mathrm{~kg}$ will lead to an increase in the rice output by $6.03 \mathrm{~kg}$ and $0.289 \%$ respectively. The positive significance of the two forms of human labour used viz. family and hired labours is an indication of absolute absorption which owed to labour intensiveness required in performing various and tedious farm operations in the rice farms with little or no case of excess for the cheaply and almost free labour sourced from farm family, and judiciously use of the hired labour owing to money cost. Thus, the marginal and elasticity implications of a unit increase in family and hired labours by 1 manday will lead to an increase in the rice output by $7.47 \mathrm{~kg}$ and $0.106 \%$ for the former; and $6.62 \mathrm{~kg}$ and $0.063 \%$ for the latter, respectively.

On the other hand, for the non-significant variables captured in the model, their sizes and signs to some extent have empirical implications. The positive non-significance of the estimated parameter for seed did not owe to the use of local variety as almost all of the farmers used improved seed variety but rather owes to improper and low adoption of the recommended quantity due to poor technical knowhow for the former and insufficient quantity owing to high cost associated with improved variety for the latter, thus exerting insignificant influence on rice output. Also, the positive non-significance of the urea and herbicides is associated with low usage below the recommended dosage owing to the high cost associated with these agro-inputs, thus not exerting significant influence on the rice output. The negative non-significance of the estimated parameter for depreciation on capital items did not come as a surprise as the farmers been smallholders used crude/primitive tools to perform virtually all the operations in their farms and these implements been replaced every cropping season due to wear and tear, the extra cost been incurred affects the output of rice in the studied area.

Furthermore, since the farmers were operating in the long-run, it was observed that the farmers were operating within the economic or rational production region as indicated by the sum of the return to scale value of 0.978 i.e. stage II which is noted to be decreasing return to scale given that the input in relation to the output at ascending level change in descending proportionate order. In other words, it implies that any extra unit of input will lead to an increasing-decreasing increase in the output level ceteris paribus, i.e. the proportionate increase in the succeeding output level will be less than that of the preceding output level. The implication is that the farmers can increase their output by efficiently utilizing the available programme recommended technologies at their disposal.

A perusal of Table 3 showed the farm size to account for the highest contribution to the output then followed by herbicides even though it was non-significant and then human labour and NPK fertilizer which are almost at par as evident by their respective marginal physical product (MPP) values. However, the seed and urea fertilizer made the least contribution to the output as indicated by their respective MPP values. The MPP value for the depreciation on capital items showed that instead of a positive contribution it made a negative contribution to the output of rice owing to use of crude implements to perform most of the operations in the farms. The technology used and the managerial efficiency increases the output of rice by $106.27 \mathrm{~kg}$ which under normal circumstances should be more than this value if the farmers complied with the recommended practices extended to them by the programme. Thus, based on the above MPP results, it can be concluded that the farmers were more technically efficient in the use of land

Since the results showed that the farmers were operating in the economic production region in which optimum production point exist, therefore, the farmers at the existing available technology need to allocate their resources efficiently keeping in view the prevailing market prices in order to 
Table 3: Technical and Allocative efficiencies of rice farmers

\begin{tabular}{llllllllll}
\hline Inputs & Mean & APP & MPP & EP & MPV & MFC & AEI & D(\%) & Decision \\
\hline Farm size & 1.33 & 3622.857 & 1475.41 & 0.40725 & 221311.5 & 5000 & 44.2623 & 97.74074 & UU \\
Seeds & 51.93 & 92.78644 & 3.985 & 0.042948 & 597.75 & 355 & 1.683803 & 40.61062 & UU \\
NPK & 230.91 & 20.867 & 6.0323 & 0.289083 & 904.845 & 160 & 5.655281 & 82.31741 & UU \\
Urea & 127.27 & 37.85967 & 2.0503 & 0.054155 & 307.545 & 160 & 1.922156 & 47.97509 & UU \\
Herbicides & 4.96 & 971.4516 & 28.1299 & 0.028957 & 4219.485 & 1500 & 2.81299 & 64.45064 & UU \\
Family labour & 68.44 & 70.40327 & 7.467 & 0.10606 & 1120.05 & 800 & 1.400063 & 28.57462 & UU \\
Paid labour & 46.14 & 104.43 & 6.6226 & 0.063417 & 993.39 & 800 & 1.241738 & 19.46768 & UU \\
Depreciation & 4170.6 & 1.155325 & -0.0161 & -0.01394 & -2.415 & 1.18 & -2.04661 & 148.8613 & OV \\
\hline
\end{tabular}

Source: Field survey, 2018

Note: $U U=$ Under-utilization; $O U=$ Over-utilization

RTS $=0.98 ;$ Output $\bar{Y}=4818.40 ; P_{y} / \mathrm{kg}=\# 150$

Table 4: MRTS of inputs used

\begin{tabular}{lllllllll}
\hline Inputs & Seeds $\downarrow$ & NPK $\downarrow$ & Urea $\downarrow$ & Herbicides $\downarrow$ & Family lab $\downarrow$ & Paid labour $\downarrow$ & Dep. $\downarrow$ & Farms $\downarrow$ \\
\hline Seeds $\uparrow$ & 1 & 0.66061 & 1.943618 & 0.141664 & 0.533682 & 0.601727 & 247.516 & 0.002701 \\
NPK $\uparrow$ & 1.513752 & 1 & 2.942155 & 0.214444 & 0.807861 & 0.910866 & 374.677 & 0.004089 \\
Urea $\uparrow$ & 0.514504 & 0.339887 & 1 & 0.072887 & 0.274581 & 0.309591 & 127.348 & 0.00139 \\
Herbicides $\uparrow$ & 7.058946 & 4.663213 & 13.71989 & 1 & 3.767229 & 4.247561 & 1747.2 & 0.019066 \\
Family labour $\uparrow$ & 1.873777 & 1.237836 & 3.641906 & 0.265447 & 1 & 1.127503 & 463.789 & 0.005061 \\
Paid labour $\uparrow$ & 1.661882 & 1.097857 & 3.230064 & 0.235429 & 0.886916 & 1 & 411.342 & 0.004489 \\
Depreciation $\uparrow$ & 0.00404 & 0.00267 & 0.00785 & 0.00057 & 0.00216 & -0.00243 & 1 & $1.1 \mathrm{E}-05$ \\
Farm size $\uparrow$ & 370.2409 & 244.585 & 719.6069 & 52.44988 & 197.5907 & 222.7841 & 91640.4 & 1
\end{tabular}

Note: $\downarrow$, means increase and decrease respectively.

maximize profit in rice production which in turn has a significant influence in sustaining the going concern of the business.

The empirical evidence showed that virtually all the resources used with the exception of depreciation on capital items were under-utilized due to poor adoption of the recommended technologies at their disposal with farm size having the highest index value of 44.26 followed by NPK fertilizer (5.66) while the remaining inputs were within the index range of less than 3 and greater than 0 (Table 3). Therefore, the output of rice is likely to increase and hence more gross income if more of these inputs were utilized and less of depreciation on capital items. Furthermore, approximately 97.74\%, $82.31 \%, 64.45 \%, 47.98 \%, 40.61 \%, 28.58 \%$ and $19.47 \%$ upward adjustments (increase) for farm size, NPK fertilizer, herbicides, urea fertilizer, seeds, free labour and paid labours respectively, are required for the attainment of optimum allocation in rice production. In addition, approximately $148.86 \%$ downward adjustment (reduction) of depreciation on capital items is required for optimum allocation. The marginal rate of technical substitution (MRTS) was estimated to show how the scale of production responds to two inputs substitution (Table 4). It was observed that the MRTS of farm size for seeds was 370.24 , implying that 1 hectare of operational size for rice can be substituted for $370.24 \mathrm{~kg}$ of seeds without changing the output scale. Also, the MRTS of herbicides for seeds was 7.08, meaning that 1litre of herbicides can be substituted for $7.08 \mathrm{~kg}$ of seeds while still maintaining the same output level. The MRTS of NPK and urea fertilizers for seeds were 1.51 and 0.52 respectively, indicating that $1 \mathrm{~kg}$ each of the NPK and urea fertilizers can be substituted for $1.51 \mathrm{~kg}$ and $0.52 \mathrm{~kg}$ of seeds respectively, without affecting the output scale of rice. The MRTS of free and paid labours for seeds were 1.87 and 1.66 respectively, indicating that 1 manday each for free and paid labours can be substituted for $1.87 \mathrm{~kg}$ and $1.66 \mathrm{~kg}$ of seeds respectively, without affecting the scale of the output. 


\section{CONCLUSION AND RECOMMENDATIONS}

Based on the empirical findings it can be inferred that the farmers were within the economic region in which economic optimum point can be attained but were not efficient in the utilization of their productive resources owing to poor adoption of the available recommended production technologies at their disposal. In addition, the market imperfections viz. input and output prices affected their efficiency in optimizing the allocation of the productive resources they employed in rice production in the studied area. Therefore, the study recommends the need to strengthen technical skill capacity build-up of the farmers viz. adequate extension advisory services delivery. However, farmer to farmer extension approach is strongly suggested for cost-cut, reduction in the bureaucratic bottleneck and unnecessary time waste associated with the conventional extension service delivery in the studied area. In addition, consumption credit should be provided to the farmers in order to make the advanced production credit viable and productive, thereby making the farmers utilize the production credit for what it's meant for rather than being diverted for capital consumption items. Also, the economic status of the farmers i.e. been resource poor, the need for the provision of subsidy on agro-chemical is very important due to market imperfection as they are operating in an environment beclouded with risks and uncertainties.

\section{REFERENCES}

Abdullahi, A.J., Atala, T.K., Akpoko, J.G. and Sanni, S.A. 2015. Factors influencing smallholder farmers' participation in IFAD-Community Based Agricultural and Rural Development Project in Katsina State. Journal of Agricultural Extension, 19(2): 93-104.

Babatunde, O. 2006. Differential poverty reduction impact of small-scale irrigated development between its beneficiaries and non-beneficiaries in Nigeria. Technical Report on the Agropolis Award.

Dawson, P.J. and Lingard, J. 1982. Management bias and returns to scale in a Cobb-Douglas production function for agriculture. European Review Agricultural Economics, 9(1): 7-24

Galadima, M. 2014. Impact of IFAD Community Based Agriculture and Rural Development Programme on Rural Livelihood in Yobe State, Nigeria. Unpublished M.Sc. Thesis submitted to the Department of Agricultural Economics and Rural Sociology, Ahmadu Bello University Zaria, Nigeria.

Gambo, D., Zahran, B.B.H. and Sidahmed, M.B.B.A. 2016. Socio-economic factors influencing the participation of the marginalized and vulnerable farmers in the IFADCommunity Based Agriculture and Rural Development Programme in Katsina State, Nigeria. Journal of Resources Development and Management, 24: 50-57

Hussain, A. 2013. Economic analysis of rice crop cultivation in District SWAT. Journal of Agricultural Research, 51(2): 175-188

IFAD-CBARDP. 2013. Programme completion Report by Katsina State Programme Support Office.

Sadiq, M.S., Singh, I.P., Lawal, M. and Ahmad, M.M. 2018. Optimization of farm resources used in sesame production in Jigawa State of Nigeria. Academic StudiesNational Journal of Jyoti Research Academy, 12(1): 45-53. 